\title{
Identification of candidate genomic regions for chicken egg number traits based on genome-wide association study
}

Xiurong Zhao ${ }^{1}$, Changsheng Nie1, Jinxin Zhang ${ }^{1}$, Xinghua Li', Tao Zhu', Zi Guan¹, Yu Chen², Liang Wang ${ }^{2}$, Xue Ze LV ${ }^{2}$, Weifang Yang ${ }^{2}$, Yaxiong Jia ${ }^{3}$, Zhonghua Ning ${ }^{1}$, Haiying $\mathrm{Li}^{4}$, Changqing $\mathrm{Qu}^{5}$, Huie Wang ${ }^{6,7}$ and Lujiang Qu ${ }^{1 *}$

\begin{abstract}
Background: Since the domestication of chicken, various breeds have been developed for food production, entertainment, and so on. Compared to indigenous chicken breeds which generally do not show elite production performance, commercial breeds or lines are selected intensely for meat or egg production. In the present study, in order to understand the molecular mechanisms underlying the dramatic differences of egg number between commercial egg-type chickens and indigenous chickens, we performed a genome-wide association study (GWAS) in a mixed linear model.

Results: We obtained 148 single nucleotide polymorphisms (SNPs) associated with egg number traits (57 significantly, 91 suggestively). Among them, 4 SNPs overlapped with previously reported quantitative trait loci (QTL), including 2 for egg production and 2 for reproductive traits. Furthermore, we identified 32 candidate genes based on the function of the screened genes. These genes were found to be mainly involved in regulating hormones, playing a role in the formation, growth, and development of follicles, and in the development of the reproductive system. Some genes such as NELL2 (neural EGFL like 2), KTLG (KIT ligand), GHRHR (Growth hormone releasing hormone receptor), NCOA1 (Nuclear receptor coactivator 1), ITPR1 (inositol 1, 4, 5-trisphosphate receptor type 1), GAMT (guanidinoacetate N-methyltransferase), and CAMK4 (calcium/ calmodulin-dependent protein kinase IV) deserve our attention and further study since they have been reported to be closely related to egg production, egg number and reproductive traits. In addition, the most significant genomic region obtained in this study was located at 48.61-48.84 Mb on GGA5. In this region, we have repeatedly identified four genes, in which YY1 (YY1 transcription factor) and WDR25 (WD repeat domain 25) have been shown to be related to oocytes and reproductive tissues, respectively, which implies that this region may be a candidate region underlying egg number traits.
\end{abstract}

Conclusion: Our study utilized the genomic information from various chicken breeds or populations differed in the average annual egg number to understand the molecular genetic mechanisms involved in egg number traits. We identified a series of SNPs, candidate genes, or genomic regions that associated with egg number, which could help us in developing the egg production trait in chickens.

Keywords: Chicken, Egg number, GWAS, SNPS, Genomic region

\footnotetext{
* Correspondence: quluj@163.com

'Department of Animal Genetics and Breeding, State Key Laboratory of Animal Nutrition, National Engineering Laboratory for Animal Breeding, College of Animal Science and Technology, China Agricultural University, Beijing 100193, China

Full list of author information is available at the end of the article
}

(c) The Author(s). 2021 Open Access This article is licensed under a Creative Commons Attribution 4.0 International License, which permits use, sharing, adaptation, distribution and reproduction in any medium or format, as long as you give appropriate credit to the original author(s) and the source, provide a link to the Creative Commons licence, and indicate if changes were made. The images or other third party material in this article are included in the article's Creative Commons licence, unless indicated otherwise in a credit line to the material. If material is not included in the article's Creative Commons licence and your intended use is not permitted by statutory regulation or exceeds the permitted use, you will need to obtain permission directly from the copyright holder. To view a copy of this licence, visit http://creativecommons.org/licenses/by/4.0/ The Creative Commons Public Domain Dedication waiver (http://creativecommons.org/publicdomain/zero/1.0/) applies to the data made available in this article, unless otherwise stated in a credit line to the data. 


\section{Background}

Reproduction traits, especially egg production, are the most important economic cares in chickens [1]. Laying performance usually reflects a chicken's reproductive performance [2]. As an important source of animal protein, the consumption of poultry eggs worldwide has increased significantly over the past few decades [3]. Each person consumes approximately $12.5 \mathrm{~kg}$ of eggs per year [4]. Egg consumption may continue to increase with accretion in urban populations $[5,6]$. Therefore, it is of great practical and economic significance to understand the genetic mechanisms of chicken reproductive traits. However, egg production is a polygenic genetic trait with low to medium heritability and is affected by both genetic components and environmental factors [7, 8]. It can be evaluated by many indicators such as age at first egg, egg number, egg production rate and so on. The egg number is an important reproductive trait in poultry breeding, an important indicator that can effectively evaluate individual egg production at a certain stage and the fertility of breeding chicken [9].

It is possible to analyze the genetic mechanisms of complex traits by using GWAS with the development of sequencing technology. GWAS can not only take full advantage of molecular markers at the genome level, but, owing to the use of whole genome sequences, avoid the effects of linkage imbalance between SNPs and underlying genes [10]. At present, a few candidate genes and regions related to egg number have been reported based on GWAS technology [9, 11-16]. According to the QTL database [17], 12,782 QTLs related to chicken economic traits have been identified, 332 of which are associated with egg number.

Some commercial lines or populations are intensively selected for their production traits. Rhode Island Red and White Leghorn chickens are well known for their distinguished egg productivity. Dwarf chickens in China have also been developed for egg production. The average annual egg number of them is approximately about 300 eggs. Chinese indigenous chickens grow relatively slowly and are known to produce less than 200 eggs per year. Therefore, we performed a GWAS based on the differences of egg number between egg-type chickens and local chickens to explore the underlying molecular genetic mechanisms and identify candidate genes or genomic regions related to egg number traits. The results of this study are supposed to be beneficial for layer breeding.

\section{Results}

\section{Population structure testing}

Principal component analysis (PCA) using the first two principal components showed that there was an obvious stratification phenomenon between Chinese indigenous chicken breeds (black circle) and commercial egg-type chickens. At the same time, we found a Tibetan chicken was mixed with White Leghorn, as shown by the red circle in Fig. 1 and (see Additional File 4: Figure S1). Meanwhile, WL_CAU and WL_YQ were divided into two groups as they came from two different population. The first principal component (PC1) and the second principal component (PC2) explain 15.92 and $7.49 \%$ of the total variance (or 59.65 and $28.08 \%$ of the top three PCs), respectively. In GWAS, population stratification might lead to false-positive results. So we used principal components as covariates correct for stratification in this study [18]. When the covariate was added as 1st PC, top two PCs, top three PCs, top four PCs and top five PCs, we performed GWAS and calculated the genomic inflation factors $(\lambda)$ respectively. $\lambda$ was $1.004,0.917,0.916$, $0.891,0.882$, respectively. When the 1 st PC was added as a covariate, $\lambda$ is the closest to 1 , indicating that the correction effect of population stratification is the best [19]. So we finally decided to add the 1 st PC in the GWAS mixed model to adjust for population stratification.

Admixture software was used to analyze the population structure. We displayed a bar plot based on the cross-validation error rate (Additional file 5: Figure S2). When $K=2$, Rhode Island Red and one of the White Leghorn groups (WL_YQ) appeared as two differentiated clusters. When $\mathrm{K}=3-4$, two White Leghorn populations (WL_CAU, WL_YQ) gathered in the same group. When $K=5$, two White Leghorn populations were separated. When $K=6-9$, the high productivity layers from four populations (WL_CAU, WL_YQ, RIR, DW) were separated, indicating that the genetic backgrounds of these layers were different (Additional file 4: Figure S1). These results reinforce the subsequent analyses.

\section{Genome-wide association study}

We took the high productivity group as the case and the low productivity group as the control, and performed GWAS on the dramatic differences in egg number between two groups.

The QQ plot was presented as Fig. 2a, the $\lambda$ was equal to 1.004 , which means that there was no population stratification phenomenon and the GWAS results were reliable.

After correction, we found 148 SNPs that could be associated with egg number (57 significantly, 91 suggestively) (Additional file 1: Table S1). The global view of $P$-values (in terms of $-\log 10$ (P-value)) for all SNPs was represented by a Manhattan plot, as shown in Fig. 2b. Table 1 lists the SNP information that was emphasized in this study. Using Ensembl to annotate related SNPs, we found a total of 68 genes around significant peaks, and identified 32 candidate genes associated with egg number according to their functions (Table 2). Some genes such as NELL2, KITLG, GHRHR, NCOA1, ITPR1, GAMT, and CAMK4, which have been proved to be related to egg number, egg 


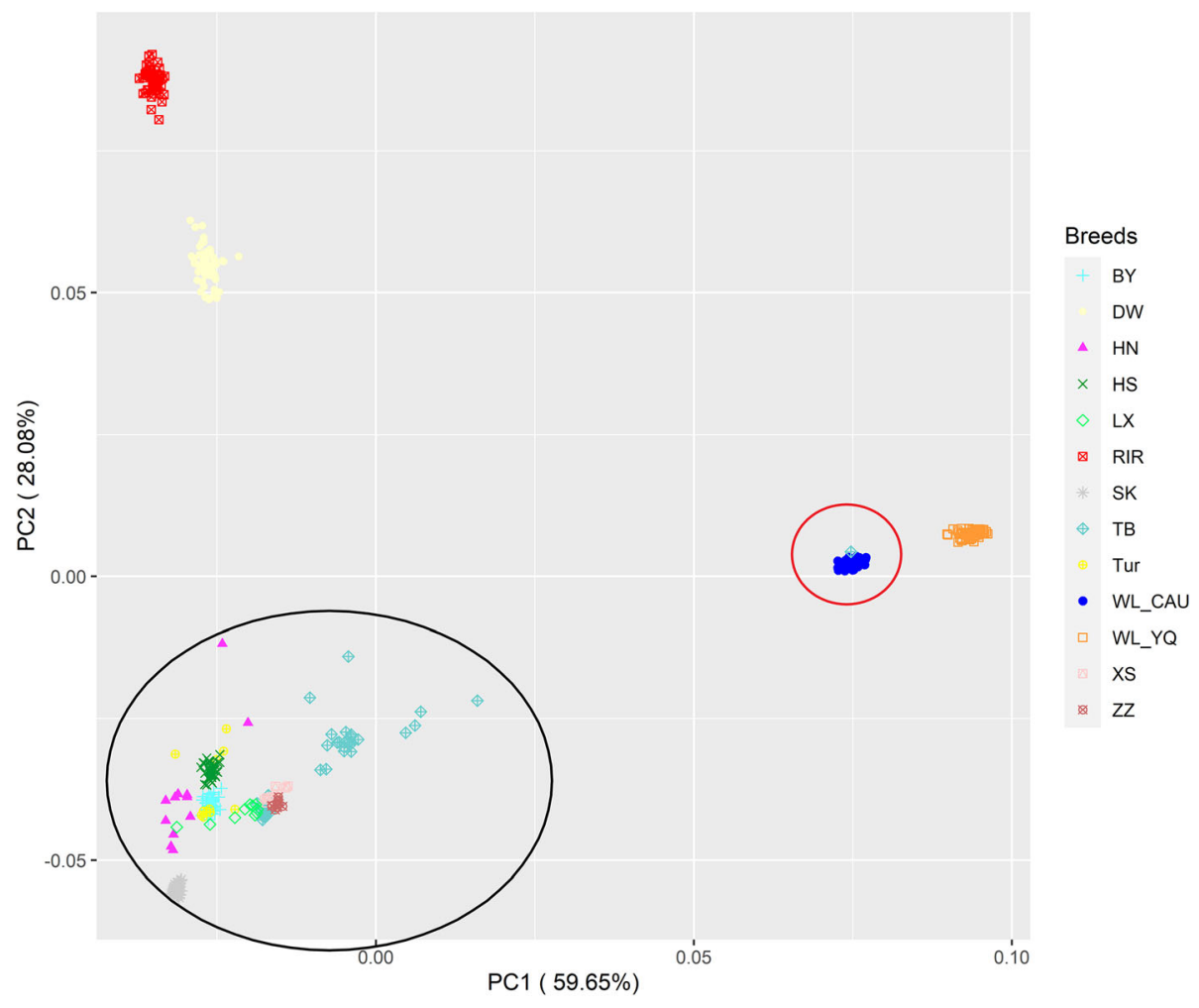

Fig. 1 PCA plot of chicken populations in this study. Each color represents a breed and the abbreviations are as defined in Table 3. PC1, principal components one; PC2, principal components two. PC1 and PC2 explain 15.92 and $7.49 \%$ of the total variance (or 59.65 and $28.08 \%$ of the top three $P(s)$, respectively

production, litter size, or reproductive traits, are worth a deeper exploration [20-33].

In addition, the most significant peak in this study was located at 48.61-48.84 Mb on chromosome 5. The chisquare test was carried out to compare the allele frequencies of the significant SNPs identified in this region between the high and low productivity groups. The results showed that the allele frequencies of these 20 SNPs were significantly different between the two groups (Additional file 2: Table S2). At the same time, four genes were repeatedly identified in this region. $Y Y 1$ is involved in oocyte growth and maturation [34]. A member

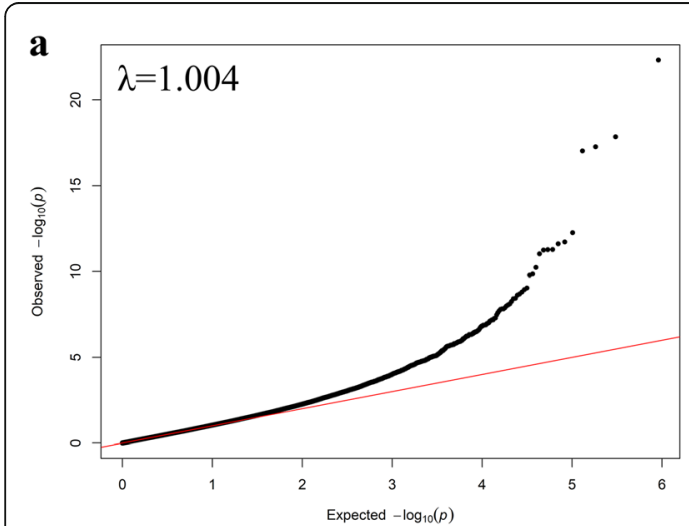

b

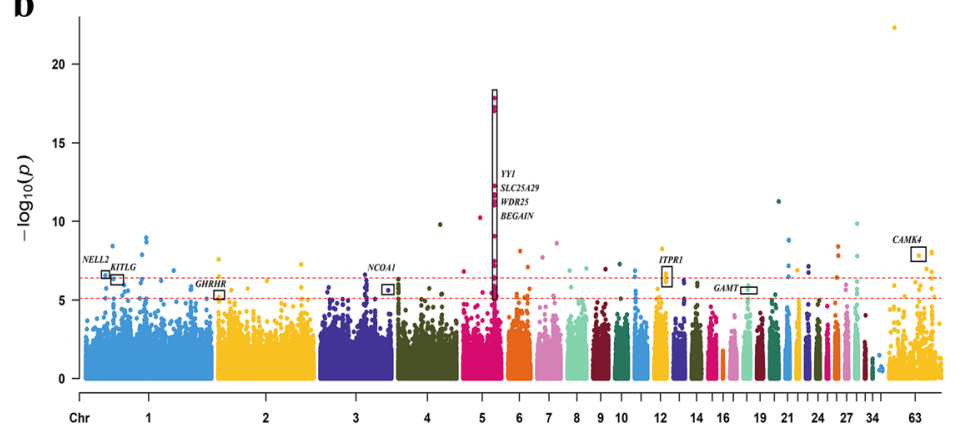

Fig. $2 \mathrm{QQ}$ plot and Manhattan of the egg number traits. a The QQ plot shows the expected -log $10 P$-value (the $x$-axis) plotted against the observed -log10 P-value (y-axis). In the top left of the QQ plot, $\lambda$ is shown as 1.004. b In Manhattan plot, the x-axis is the position of each SNP on the chicken chromosomes (34, 40, 63 indicate LEG64, W, and Z respectively), and the $y$-axis is the -log10 P-value. The horizontal red dotted line at the top indicates the genome-wide significant thresholds is $3.91 \times 10^{-7}$, line at the bottom represents the genome-wide suggestively thresholds is $7.82 \times 10^{-6}$ 
Table 1 Genome-wide SNPs around significant peaks associated with egg number traits

\begin{tabular}{|c|c|c|c|c|}
\hline SNP ID & Chromosome & Posistion $^{a}$ & $P$ value & Nearest gene \\
\hline AX-75424481 & 1 & 30418287 & $2.69 \mathrm{E}-07$ & NELL2 \\
\hline AX-75424489 & 1 & 30420285 & 7.69E-06 & NELL2 \\
\hline AX-75427140 & 1 & 31722672 & 1.80E-06 & LRIG3 \\
\hline AX-75448176 & 1 & 41739240 & 3.62E-09 & TSPAN19 \\
\hline AX-75450814 & 1 & 43099910 & $4.52 \mathrm{E}-07$ & KITLG \\
\hline AX-75499001 & 1 & 65863432 & $2.52 \mathrm{E}-06$ & ENSGALG00000046127 \\
\hline AX-75225234 & 1 & $1.18 \mathrm{E}+08$ & $5.79 \mathrm{E}-07$ & ENSGALG00000036169 \\
\hline AX-75320912 & 1 & $1.63 \mathrm{E}+08$ & $2.17 \mathrm{E}-06$ & PCDH17 \\
\hline AX-75322789 & 1 & $1.64 \mathrm{E}+08$ & $2.13 \mathrm{E}-06$ & ENSGALG00000034638 \\
\hline AX-75322810 & 1 & $1.64 \mathrm{E}+08$ & $1.38 \mathrm{E}-06$ & ENSGALG00000034638 \\
\hline AX-75965321 & 2 & 1068425 & $2.52 \mathrm{E}-08$ & MINDY4, AQP1 \\
\hline AX-75993000 & 2 & 1215757 & $6.42 \mathrm{E}-06$ & GHRHR \\
\hline AX-75996755 & 2 & 1234625 & $3.13 \mathrm{E}-07$ & GHRHR \\
\hline AX-76053674 & 2 & 20576504 & $2.35 \mathrm{E}-06$ & FAM171A1 \\
\hline AX-80779498 & 2 & 46145450 & $1.88 \mathrm{E}-06$ & TRANK1 \\
\hline AX-76003273 & 2 & $1.3 \mathrm{E}+08$ & 5.33E-08 & AZIN1 \\
\hline AX-76003319 & 2 & $1.3 \mathrm{E}+08$ & $1.55 \mathrm{E}-06$ & AZIN1 \\
\hline AX-76536054 & 3 & 69621540 & $2.42 \mathrm{E}-07$ & $N A$ \\
\hline AX-76536071 & 3 & 69628923 & $1.59 \mathrm{E}-06$ & $N A$ \\
\hline AX-76536096 & 3 & 69655624 & 4.14E-06 & $N A$ \\
\hline AX-76536308 & 3 & 69762163 & $5.02 \mathrm{E}-06$ & $N A$ \\
\hline AX-76540844 & 3 & 72000979 & $5.65 \mathrm{E}-07$ & POU $3 F 2, F B X L 4$ \\
\hline AX-76541349 & 3 & 72227940 & $9.78 \mathrm{E}-07$ & ENSGALG00000034564 \\
\hline AX-76541394 & 3 & 72243677 & 7.32E-06 & ENSGALG00000034564 \\
\hline AX-76541486 & 3 & 72303465 & $2.23 \mathrm{E}-06$ & ENSGALG00000034564 \\
\hline AX-76541488 & 3 & 72304623 & $1.32 \mathrm{E}-06$ & ENSGALG00000034564 \\
\hline AX-76401421 & 3 & $1.06 \mathrm{E}+08$ & $2.40 \mathrm{E}-06$ & NCOA1 \\
\hline AX-76624455 & 4 & 141350 & $1.78 \mathrm{E}-06$ & MSN \\
\hline AX-76630762 & 4 & 173004 & $4.71 \mathrm{E}-07$ & MSN \\
\hline AX-76645558 & 4 & 249014 & $3.49 \mathrm{E}-06$ & ENSGALG00000044799 \\
\hline AX-76652327 & 4 & 283517 & $1.22 \mathrm{E}-06$ & HEPH, HSF3 \\
\hline AX-76658977 & 4 & 319076 & $1.94 \mathrm{E}-06$ & HEPH, GPR83L \\
\hline AX-76662643 & 4 & 338418 & $1.02 \mathrm{E}-06$ & GPR83L, ENSGALG00000038728 \\
\hline AX-80823531 & 4 & 394383 & $1.51 \mathrm{E}-06$ & $N A$ \\
\hline AX-76676155 & 4 & 408469 & $4.71 \mathrm{E}-07$ & $N A$ \\
\hline AX-76714260 & 4 & 612204 & $3.23 \mathrm{E}-06$ & ENSGALG00000029764 \\
\hline AX-76718681 & 4 & 634832 & 2.09E-06 & ENSGALG00000029764 \\
\hline AX-76675026 & 4 & 48646624 & $1.82 \mathrm{E}-06$ & ADGRL3 \\
\hline AX-76713110 & 4 & 67434214 & 4.37E-06 & ENSGALG00000041624, GABRA2, GABRA4 \\
\hline AX-76715084 & 4 & 68430908 & 4.09E-06 & GRXCR1 \\
\hline AX-76776179 & 5 & 1133440 & $1.52 \mathrm{E}-07$ & LUZP2 \\
\hline AX-76814849 & 5 & 30327067 & $3.26 \mathrm{E}-06$ & RYR3 \\
\hline AX-76845554 & 5 & 44381627 & $3.63 \mathrm{E}-06$ & CCDC88C, PPP4R3A \\
\hline AX-76855266 & 5 & 48607009 & $3.72 \mathrm{E}-06$ & $Y Y 1, S L C 25 A 29$ \\
\hline
\end{tabular}


Table 1 Genome-wide SNPs around significant peaks associated with egg number traits (Continued)

\begin{tabular}{|c|c|c|c|c|}
\hline SNP ID & Chromosome & Posistion $^{a}$ & $P$ value & Nearest gene \\
\hline AX-76855305 & 5 & 48622650 & $1.28 \mathrm{E}-06$ & $S L C 25 A 29, Y Y 1$ \\
\hline AX-76855335 & 5 & 48635048 & $1.45 \mathrm{E}-06$ & $S L C 25 A 29$ \\
\hline AX-76855457 & 5 & 48687658 & $3.62 \mathrm{E}-07$ & WDR25 \\
\hline AX-76855519 & 5 & 48714129 & $6.08 \mathrm{E}-06$ & WDR25 \\
\hline AX-76855557 & 5 & 48731601 & $9.56 \mathrm{E}-12$ & WDR25 \\
\hline AX-76855561 & 5 & 48733361 & $3.33 \mathrm{E}-08$ & WDR25 \\
\hline AX-76855583 & 5 & 48739609 & $5.29 \mathrm{E}-12$ & BEGAIN \\
\hline AX-76855593 & 5 & 48745253 & $5.31 \mathrm{E}-18$ & BEGAIN \\
\hline AX-76855630 & 5 & 48762022 & $6.51 \mathrm{E}-08$ & BEGAIN \\
\hline AX-76855665 & 5 & 48778313 & $4.22 \mathrm{E}-07$ & BEGAIN \\
\hline AX-76855684 & 5 & 48786534 & $9.28 \mathrm{E}-18$ & BEGAIN \\
\hline AX-76855699 & 5 & 48792877 & $1.40 \mathrm{E}-18$ & BEGAIN \\
\hline AX-76855705 & 5 & 48795578 & $1.94 \mathrm{E}-12$ & BEGAIN \\
\hline AX-76855726 & 5 & 48804374 & 2.31E-06 & BEGAIN \\
\hline AX-80949259 & 5 & 48808664 & 1.61E-06 & BEGAIN \\
\hline AX-76855747 & 5 & 48811664 & $9.02 \mathrm{E}-10$ & BEGAIN \\
\hline AX-76855766 & 5 & 48820492 & $5.54 \mathrm{E}-13$ & BEGAIN \\
\hline AX-76855815 & 5 & 48838402 & $2.48 \mathrm{E}-12$ & BEGAIN \\
\hline AX-76855817 & 5 & 48839325 & $5.76 \mathrm{E}-12$ & BEGAIN \\
\hline AX-76900556 & 6 & 13775431 & 4.09E-06 & KCNMA1 \\
\hline AX-76900629 & 6 & 13799359 & $6.36 \mathrm{E}-06$ & KCNMA1 \\
\hline AX-76943077 & 6 & 30466599 & $5.62 \mathrm{E}-06$ & $N A$ \\
\hline AX-77011457 & 7 & 25213170 & $5.44 \mathrm{E}-06$ & $N A$ \\
\hline AX-77014656 & 7 & 26516128 & $6.78 \mathrm{E}-06$ & $S L C 15 A 2, I Q C B 1$ \\
\hline AX-75660603 & 11 & 445721 & $3.26 \mathrm{E}-07$ & CSNK2A2 \\
\hline AX-75665353 & 11 & 607645 & $1.34 \mathrm{E}-07$ & POLR2C \\
\hline AX-75643828 & 11 & 1608025 & $2.68 \mathrm{E}-06$ & HYDIN \\
\hline AX-75644090 & 11 & 1618412 & 7.76E-06 & HYDIN \\
\hline AX-80948010 & 11 & 1754582 & 4.07E-06 & VAC14 \\
\hline AX-75703508 & 12 & 18557458 & $5.27 \mathrm{E}-07$ & ITPR1 \\
\hline AX-75703529 & 12 & 18564932 & $2.08 \mathrm{E}-07$ & ITPR1 \\
\hline AX-75703541 & 12 & 18569966 & 2.87E-07 & ITPR1 \\
\hline AX-75703548 & 12 & 18572141 & $6.83 \mathrm{E}-07$ & ITPR1 \\
\hline AX-75744414 & 13 & 16244175 & $5.66 \mathrm{E}-07$ & VDAC1 \\
\hline AX-75745363 & 13 & 16603463 & $8.21 \mathrm{E}-07$ & ENSGALG00000029896 \\
\hline AX-75810149 & 14 & 8804646 & $1.25 \mathrm{E}-06$ & OTOA \\
\hline AX-75810223 & 14 & 8826708 & $8.41 \mathrm{E}-07$ & OTOA \\
\hline AX-75906835 & 18 & 6994110 & $2.21 \mathrm{E}-06$ & SMURF2 \\
\hline AX-80787269 & 18 & 7876592 & $1.18 \mathrm{E}-06$ & ARSG, SLC16A6 \\
\hline AX-76227922 & 20 & 8585474 & $4.52 \mathrm{E}-06$ & ENSGALG00000039201, ENSGALG00000005652 \\
\hline AX-76249257 & 21 & 4983824 & $3.25 \mathrm{E}-07$ & $K A Z N$ \\
\hline AX-76249303 & 21 & 4996326 & $6.51 \mathrm{E}-08$ & $K A Z N$ \\
\hline AX-76250675 & 21 & 5263523 & 1.55E-09 & C1orf158, ENSGALG00000021598 \\
\hline$A X-76288938$ & 23 & 4139841 & $1.78 \mathrm{E}-07$ & $N A$ \\
\hline
\end{tabular}


Table 1 Genome-wide SNPs around significant peaks associated with egg number traits (Continued)

\begin{tabular}{|c|c|c|c|c|}
\hline SNP ID & Chromosome & Posistion $^{a}$ & $P$ value & Nearest gene \\
\hline AX-80768216 & 23 & 4214468 & 7.13E-08 & AGO1 \\
\hline AX-76339015 & 26 & 3035521 & $3.58 \mathrm{E}-07$ & $N A$ \\
\hline AX-76348623 & 26 & 5077655 & 3.82E-09 & TAF8 \\
\hline AX-76348772 & 26 & 5100952 & 1.49E-08 & CHIA \\
\hline AX-76379082 & 28 & 2980442 & 4.15E-06 & SBNO2 \\
\hline AX-76379816 & 28 & 3170288 & 3.73E-06 & $N A$ \\
\hline AX-76379939 & 28 & 3197429 & $1.98 \mathrm{E}-06$ & GAMT, DAZAP1 \\
\hline AX-76380005 & 28 & 3210016 & $6.59 \mathrm{E}-07$ & $D A Z A P 1$ \\
\hline AX-76380342 & 28 & 3284684 & 1.57E-08 & SLC39A3 \\
\hline AX-76380390 & 28 & 3295475 & 1.40E-10 & SLC39A3, DIRAS \\
\hline AX-77265370 & 63 & 8262232 & 1.19E-06 & CNTFR \\
\hline AX-77206121 & 63 & 24853011 & $5.82 \mathrm{E}-06$ & $N A$ \\
\hline AX-77226182 & 63 & 46670667 & $1.48 \mathrm{E}-08$ & САMK4 \\
\hline AX-77226564 & 63 & 46942411 & 2.19E-06 & $N A$ \\
\hline AX-77228575 & 63 & 49223728 & $1.22 \mathrm{E}-06$ & $N A$ \\
\hline AX-77252226 & 63 & 66675375 & 4.08E-07 & MUSK \\
\hline AX-77252227 & 63 & 66676347 & $1.56 \mathrm{E}-07$ & MUSK \\
\hline AX-77252241 & 63 & 66683942 & 1.89E-06 & MUSK \\
\hline AX-77252265 & 63 & 66694071 & 8.69E-09 & MUSK \\
\hline AX-80869954 & 63 & 66732038 & 1.01E-08 & MUSK \\
\hline
\end{tabular}

${ }^{a}$ Physical position

of the solute carrier family 25 (SLC25A29) is involved in the transport of amino acids. WDR25 may be related to the reproductive tissues [35]. Brain enriched guanylate kinase $(B E G A I N)$ is a gene specifically expressed in the brain and is involved in the regulation of postsynaptic neurotransmitter receptor activity [36].

\section{Comparing with previously reported QTLs}

Through Animal QTLdb, we detected 4 QTLs that overlapped with SNPs obtained from this study. Two of

Table 2 Details for 32 candidate genes that influence egg number traits in different ways

\begin{tabular}{ll}
\hline $\begin{array}{l}\text { Ways impacting } \\
\text { reproductive traits }\end{array}$ & Genes \\
\hline Regulating hormone level & $\begin{array}{l}\text { NELL2, AQP1, AZIN1, POU3F2, } \\
\text { POLR2C, GPR83L, ENSG } \\
\text { ALG00000038728, RYR3, ITPR1, CNTF } \\
R\end{array}$ \\
& $\begin{array}{l}\text { LRG3, KITLG, PCDH17, GHRHR, ADGR } \\
\text { Influencing the formation, } \\
\text { growth, development of follicle }\end{array}$ \\
& $\begin{array}{l}\text { ITPR1, SMURF2, AGO1, CHIA, DAZAP1, } \\
\text { DIRAS1, MUSK, CAMK4 }\end{array}$ \\
Influencing the development & $\begin{array}{l}\text { WDR25, ENSGALG00000029896, ENSG } \\
\text { of the reproductive system }\end{array}$ \\
& $\begin{array}{l}\text { ALG00000039201, GAMT, DAZAP1, } \\
\text { ESGALG00000005652, SLC39A3, } \\
\text { HYDIN }\end{array}$ \\
\hline
\end{tabular}

these 4. QTLs were associated with egg production, including 1 with egg production rate and 1 with small yellow follicle number. The remaining QTLs were related to reproductive traits, including 2 with ovary weight (Additional file 3: Table S3).

\section{Discussion}

\section{GWAS and QTL overlapping}

An important condition for GWAS to achieve better results is to eliminate false associations caused by differences in allele frequencies arising from population stratification, recessive kinship, and genotyping errors [37]. The GEMMA adopted in this study considers the group stratification and sample structure. At the same time, we also added the $\mathrm{PC} 1$ as a covariate to reduce the group stratification effect. The results of the QQ plot and $\lambda$ show that the correction effect is good, and there is no population stratification phenomenon.

Four of the 148 QTLs in this study were those identified in previous studies. Among these overlapping QTLs, 2 QTLs were associated with egg production. This reinforces the results of our study. AX-75745363 is located the ENSGALG00000029896 gene on chromosome 13. AX-76715084 is located $0.046 \mathrm{Mb}$ upstream of the GRXCR1 (glutaredoxin and cysteine-rich domain containing 1) gene on chromosome 4. Although these genes 
have not been very well studied in chickens, and their functions have not been fully elucidated, they provide a reference and idea to understand the molecular mechanism for egg number traits.

\section{Candidate genes}

As far as we know, this study has the largest variety of breeds so far in the research of reproductive traits in chicken, which not only improves the detection ability of related QTLs, but also allows us to detect some QTLs related to fat and heat resistance. We speculate that this was due to the relatively slow fat formation and deposition $[38,39]$ and the relatively high heat generation of layers [40]. Thus, we identified 32 candidate genes based on their function. These genes mainly affect egg number in three ways (Table 2). Some genes regulate hormone levels, including gonadotropin-releasing hormone $(\mathrm{GNRH})$, oxytocin $(\mathrm{OXT})$, growth hormone $(\mathrm{GH})$, and thyroid hormone $(\mathrm{TH})$. All these hormones play a vital role in the female reproductive system [41-46]. Some genes affect egg number traits by affecting the growth and development of follicles. It is well known that the growth and development of follicles are critical for reproductive function, especially in chickens. The remaining genes directly affect reproductive system development. Among these 32 candidate genes, we also found 7 important genes that have been identified as related to reproductive traits such as egg production, egg number and litter size in previous studies, which further validates our findings. NELL2 and KITLG are located on GGA1. NELL2 not only affects the synthesis and secretion of GNRH [47], but has also been shown to be involved in maintaining the normal female reproductive cycle of mammals [20]. KITLG plays an important role in the growth and development of follicles [21, 48]. It has been shown to be related to the litter size of goat and sheep, and has been considered an excellent candidate gene for reproductive traits of humans and livestock [21-23]. Therefore, it is reasonable to speculate that KITLG has an important impact on egg number traits. GHRHR located on GGA2 participates in the secretion and synthesis of GH. It is believed to be involved in the growth and reproduction of livestock [49]. Liu et al. identified three SNPs in the GHRHR promoter that are significantly related to egg number traits in Beijing You chickens [24]. NCOA1, located on GGA3, is involved in

Table 3 Summary of phenotypic data

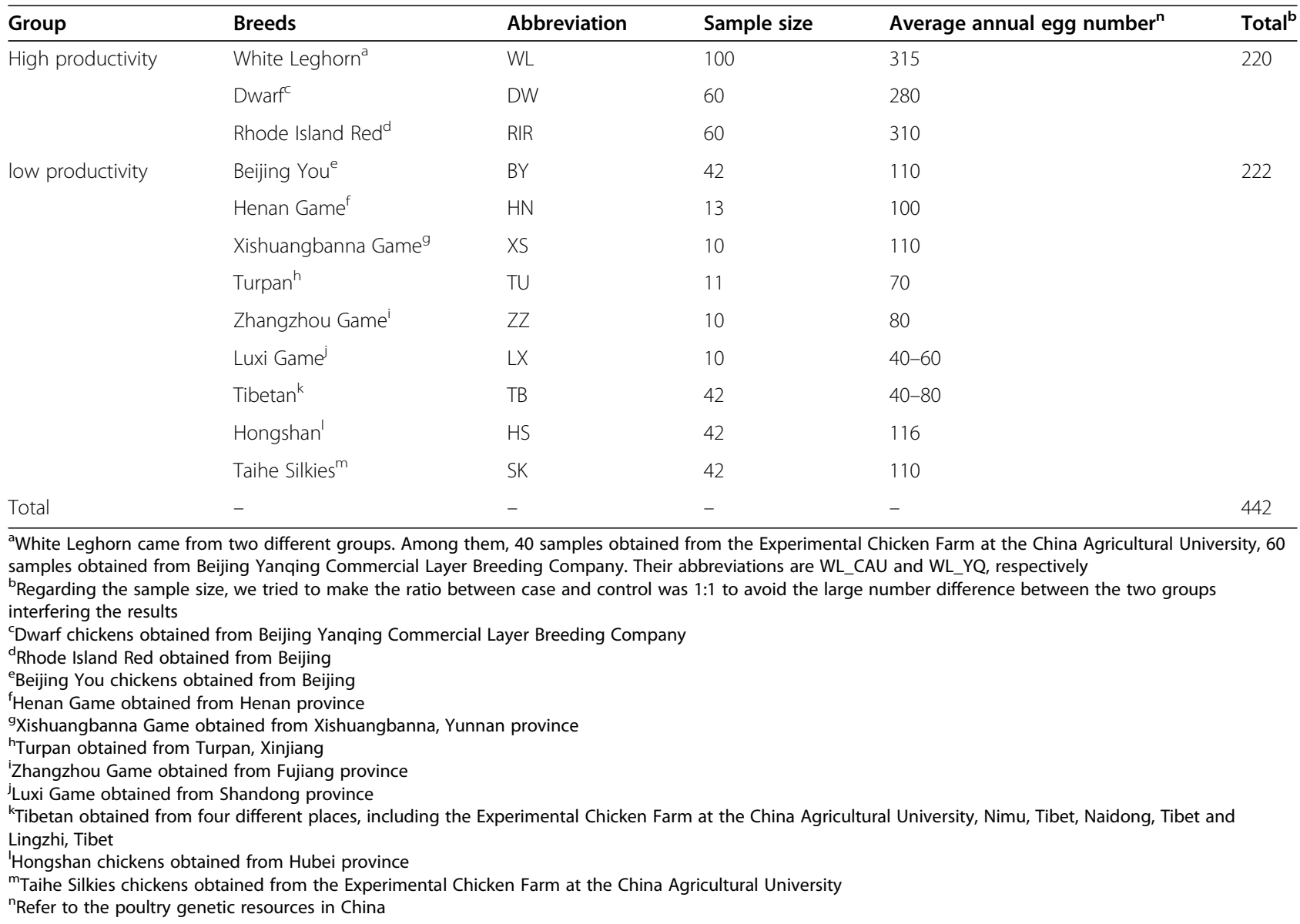


regulating signal pathways mediated by $\mathrm{TH}$ and estrogen. It has not only been shown to be an important gene that influences reproductive traits in pigs and sheep, but also related to egg production, fertility, and reproductive traits in chicken [25-30]. ITPR1 repeatedly identified in the $18.56-18.57 \mathrm{Mb}$ on chromosome 12 can not only participate in the signaling pathway of $\mathrm{GnRH}$, estrogen, and the synthesis and secretion of $\mathrm{GH}$ and $\mathrm{TH}$, but also affects the growth and differentiation of follicles. In addition, ITPR1 has been reported to be involved in the transport of $\mathrm{Ca}^{2+}$ and may be associated with egg number [31]. This suggests that this region located on chromosome 12 and the ITPR1 gene may be important for chicken egg number traits. GAMT located on GGA28 has been shown to be associated with the reproductive system and development [32]. CAMK4 located on chromosome $\mathrm{Z}$ is involved in the signaling pathway of OXT and may play a role in the development of follicles and ovulation [50]. It is believed to play a significant role in the reproductive processes of females [33].

However, NELL2, GAMT, and CAMK4 have not been studied before in chickens, and the results of this study may pave the way for future researchers to explore the relationship between these genes and egg number traits. Also, the specific functions of these genes need to be further verified.

\section{Candidate region}

In this study, the most significant peak obtained was located at $48.61-48.84 \mathrm{Mb}$ region on GGA5. In this region, $Y Y 1, S L C 25 A 29, W D R 25$, and BEGAIN were annotated. Among them, $Y Y 1$ and WDR25 have been shown to be related to oocytes and reproductive tissues, respectively [34, 35]. However, there is no concrete literature to prove that they are associated with egg number traits in chickens, thus further research is still required. At the same time, interestingly enough, a number of studies have detected regions associated with egg number traits on chromosome $5[12,15]$. The region identified in our study was about $1.2 \mathrm{Mb}$ away from the QTL reported by Zhang et al. [15]. Although the results are different, it has once again proved that chromosome 5 is an important candidate region that affects the reproductive traits of chickens.

\section{Conclusions}

In this study, we performed a GWAS based on the difference of egg number between high productivity layers and Chinese indigenous chickens and identified a series of SNPs and candidate genes related to reproductive traits. Four of the SNP effects overlapped with previously reported QTL regions, which supports the results of this study. These results may help us to better understand the molecular mechanisms underlying reproductive traits in chickens and even other species.

\section{Materials and methods}

\section{Experimental animals}

For this study, 442 chicks were available. Among them, White Leghorn and Rhode Island Red are intensively selected commercial breed, Dwarf Chicken is a synthetic layer line. Both they are egg-type chickens and produce about 300 eggs per year. They were placed in the high egg productivity group in this study. The other ten Chinese indigenous breeds laying less than 200 eggs annually were classified into the low egg productivity group. The details of the samples are presented in Table 3.

\section{Genotyping and quality control}

In total, blood samples from 442 chickens from the high and low egg productivity groups were collected by standard venipuncture. After DNA extraction using the standard phenol/chloroform method [51], the chickens were genotyped using a $600 \mathrm{~K}$ Affymetrix Axiom Chicken Genotyping Array with a total of 580,961 SNPs [52]. Quality control was performed using Plink v1.9 [53]. SNPs with a minor allele frequency $\geq 1 \%$ and genotyping rate $\geq 98 \%$ were retained. Individuals with a genotype deletion rate of $>5 \%$ were excluded. SNPs with HardyWeinberg equilibrium $P<10^{-6}$ were eliminated. After filtering, 439 chickens, including 218 in high and 221 in low egg productivity groups, and 456,647 SNPs were retained for further analyses.

\section{Population structure analysis}

Prior to GWAS, population structure was examined by PCA. Plink 1.9 was used to determine the population structure and generate eigenvectors and eigenvalues, and the "ggplot2" package in $\mathrm{R}$ studio was used to visualize the results of PCA. We selected the first two principal components with the largest variance interpretation rate as the horizontal and vertical coordinates to create a PCA plot. At the same time, we calculated the principal component contribution rate based on 439 eigenvalues.

We retained relatively dependent SNPs with the plink '--indep-pairwise 2550.2 ' command. The genetic structure was estimated using Admixture software [54]. We calculated the ancestor coefficient matrix, simulated the situation of genetic clusters (K) from 1 to 20, and computed the cross-validation error rate. Furthermore, we used an online pophelper to display a population structure bar plot (http:// pophelper.com/) [55].

\section{Genome-wide association study}

GWAS analyses of the egg number were performed using a univariate mixed linear model in GEMMA [56]. In the current study, only the PC1 was used as a 
covariate to correct population stratification. The model is as follows:

$$
\mathrm{y}=\mathrm{W} \alpha+\mathrm{x} \beta+\mathrm{u}+\varepsilon
$$

where $y$ denotes a phenotypic value vector of 439 individuals, $W$ is a matrix of covariates (fixed effects that contain a column of $1 \mathrm{~s}$ and the first principal component), $\alpha$ represents a vector of the corresponding coefficients consisting of intercepts, $x$ is a vector of marker genotypes, $\beta$ is the effect size of a marker, $u$ is a vector of random effects with a covariance structure that follows a normal distribution as $u \sim \mathrm{N}(0, \mathrm{KVg})$, where $\mathrm{K}$ is a genetic relationship matrix and $\mathrm{Vg}$ is the polygenic additive variance; and $\varepsilon$ is a vector of random residuals. In this study, the Wald statistic was used to test each SNP.

Manhattan and Quantile-Quantile (QQ) plot were made by R package "CMplot" and "qqman" respectively, and we also calculated $\lambda$ based on $p$-values from GWAS to judge the degree of false-positive [57]. $\lambda$ was calculated by the median of the resulting chi-squared test statistics divided by the expected median of the chisquared distribution. We set the median of a chisquared distribution with one degree of freedom was 0.454 in this study.

The traditional Bonferroni correction is too strict, resulting in a higher false-negative rate and omission of some SNPs truly associated with the target trait [58]. Therefore, in this study, we calculated the sum of the number of independent SNPs and LD blocks for correction [59]. The effective number of independent tests was 127,862 in this study. Hence, the threshold $P$ value was adjusted to $3.91 \times 10^{-7}$ for a genome-wide significance level, and $7.82 \times 10^{-6}$ for a genome-wide suggestive significance level. This means that SNPs with $P$ values below $7.82 \times 10^{-6}$ are considered and may be associated with egg number traits.

\section{Bioinformatics analysis of candidate genes}

We identified candidate genes by searching for the nearest genes located within $400 \mathrm{bp}$ upstream or downstream of the significant associated SNPs and annotated based on the Galgal 5.0 assembly supported by Ensembl (http://www. ensembl.org/index.html) databases. We then checked the biological functions of these genes in PubMed (https:// pubmed.ncbi.nlm.nih.gov).

\section{Overlap with known QTLs}

In addition, regions within $100 \mathrm{~kb}$ of a candidate SNP were searched for previously reported QTLs with egg number, egg production or reproductive traits in the chicken QTL database (https://www.animalgenome.org/ cgi-bin/QTLdb/GG/index).

\section{Abbreviations}

GWAS: Genome-wide association study; SNPs: Single nucleotide polymorphisms; QTL: Quantitative trait loci; PCA: Principal component analysis; $\lambda$ : Genomic inflation factors

\section{Supplementary Information}

The online version contains supplementary material available at https://doi. org/10.1186/s12864-021-07755-3.

Additional file 1: Table S1. Genome-wide SNPs associated with egg number traits.

Additional file 2: Table S2. Difference of the allele frequencies of the significant SNPs located at 48.61-48.84 Mb on chromosome 5 between the high and low productivity groups.

Additional file 3: Table S3. Results for comparison with previously reported QTLs. ${ }^{a}$ The unit is Mb. U and D represent that SNP located upstream and downstream of the gene, respectively. ${ }^{b}$ The unit is $\mathrm{Mb} . \mathrm{U}$ and D represent that SNP located upstream and downstream of the gene, respectively.

Additional file 4: Figure S1. Admixture plot. Each color represents separate groups, each line represents a group value.

Additional file 5: Figure S2. The line chart of cross validation error. The coefficient of variation value for each K-value, the accessions were divided into 20 subgroups (there was minimum $K$-value when $K=12$ ).

\section{Acknowledgments}

We are grateful for all of our colleagues of the Poultry Team of the National Engineering Laboratory for Animal Breeding of China Agricultural University.

\section{Authors' contributions}

LQ and ZN conceived and designed the experiment. XZ performed bioinformatics analyses. CN, JZ, XLi, TZ, ZG, WY and XZ performed the experiments and interpreted the result data. YC, LW, XLv, YJ, HL, CQ and HW contributed resources and funding. $L Q$ and $X Z$ led the manuscript writing. All authors read and approved the final manuscript.

\section{Funding}

This work was funded by the earmarked fund for the Beijing Innovation Team of the Modern Agro-industry Technology Research System (BAIC042021); Anhui Province Science and Technology Major Special Project (202003a06020020, 201904f06020018); Key Natural Science Research Project of Anhui Province, Department of Education (KJ2020A0520); Cooperative Innovation Project of universities in Anhui Province (GXXT-2019-049).

Availability of data and materials

The datasets generated for this study can be found in FigShare https:// figshare.com/s/7592d6524d1af7acfdb7.

\section{Declarations}

Ethics approval and consent to participate We confirm that that standard guidelines were followed for all the experimental protocols related to animal experimentation in this study were reviewed and approved by the Animal Welfare Committee of China Agricultural University. The study was carried out in compliance with the ARRIVE guidelines. For consent to participate is not applicable in this study.

Consent for publication

Not applicable.

\section{Competing interests}

The authors declare that they have no competing interests.

\section{Author details}

'Department of Animal Genetics and Breeding, State Key Laboratory of Animal Nutrition, National Engineering Laboratory for Animal Breeding, College of Animal Science and Technology, China Agricultural University, Beijing 100193, China. ${ }^{2}$ Beijing Municipal General Station of Animal Science, 
Beijing 100107, China. ${ }^{3}$ Institute of Animal Sciences, Chinese Academy of Agricultural Sciences, Beijing 100193, China. ${ }^{4}$ College of Animal Science, Xinjiang Agricultural University, Urumqi 830000, China. ${ }^{5}$ Engineering Technology Research Center of Anti-aging Chinese Herbal Medicine of Anhui Province, Fuyang Normal University, Fuyang 236037, Anhui, China. ${ }^{6}$ College of Animal Science, Tarim University, Alar 843300, Xingjiang, China. ${ }^{7}$ Key Laboratory of Tarim Animal Husbandry Science and Technology, Xinjiang Production \& amp; Construction Corps, Alar 843300, Xingjiang, China.

\section{Received: 15 January 2021 Accepted: 25 May 2021}

\section{Published online: 10 August 2021}

\section{References}

1. Liu WJ, Sun DX, Yu Y, Li G, Tang SQ, Zhang Y, et al. Association of Janus kinase 2 polymorphisms with growth and reproduction traits in chickens. Poult Sci. 2010;89(12):2573-9. https://doi.org/10.3382/ps.2010-00988.

2. Du Y, Liu L, He Y, Dou T, Jia J, Ge C. Endocrine and genetic factors affecting egg laying performance in chickens: a review. Br Poult Sci. 2020;61(5):53849. https://doi.org/10.1080/00071668.2020.1758299.

3. Mueller S, Kreuzer M, Siegrist M, Mannale K, Messikommer RE, Gangnat IDM. Carcass and meat quality of dual-purpose chickens (Lohmann dual, Belgian Malines, Schweizerhuhn) in comparison to broiler and layer chicken types. Poult Sci. 2018;97(9):3325-36. https://doi.org/10.3382/ps/pey172.

4. Hjellnes V, Šližyte R, Rustad T, Carvajal AK, Greiff K. Utilization of egg-laying hens (Gallus Gallus domesticus) for production of ingredients for human consumption and animal feed. BMC Biotechnol. 2020;20(1):22. https://doi. org/10.1186/s12896-020-00618-x.

5. Yang Z, Rose SP, Yang HM, Pirgozliev V, Wang ZY. Egg production in China. World's Poultry Sci J. 2018;74(3):417-26. https://doi.org/10.1017/S004393391 8000429.

6. Goto T, Fernandes AFA, Tsudzuki M, Rosa GJM. Causal phenotypic networks for egg traits in an F (2) chicken population. Mol Gen Genomics. 2019; 294(6):1455-62. https://doi.org/10.1007/s00438-019-01588-2.

7. Zhang L, Li DY, Liu YP, Wang Y, Zhao XL, Zhu Q. Genetic effect of the prolactin receptor gene on egg production traits in chickens. Genet Mo Res. 2012;11(4):4307-15. https://doi.org/10.4238/2012.October.2.1.

8. Qin N, Liu Q, Zhang YY, Fan XC, Xu XX, Lv ZC, et al. Association of novel polymorphisms of forkhead box L2 and growth differentiation factor-9 genes with egg production traits in local Chinese Dagu hens. Poult Sci. 2015;94(1):88-95. https://doi.org/10.3382/ps/peu023.

9. Liu Z, Yang N, Yan Y, Li G, Liu A, Wu G, et al. Genome-wide association analysis of egg production performance in chickens across the whole laying period. BMC Genet. 2019;20(1):67. https://doi.org/10.1186/s12863-019-0771-7.

10. Wang J, Yuan X, Ye S, Huang S, He Y, Zhang H, et al. Genome wide association study on feed conversion ratio using imputed sequence data in chickens. Asian-Australas J Anim Sci. 2019;32(4):494-500. https://doi.org/10. 5713/ajas.18.0319.

11. Dong X, Li J, Zhang Y, Han D, Hua G, Wang J, et al. Genomic analysis reveals pleiotropic alleles at EDN3 and BMP7 involved in chicken comb color and egg production. Front Genet. 2019;10:612. https://doi.org/10.3389/ fgene.2019.00612.

12. Wolc A, Arango J, Jankowski T, Dunn I, Settar P, Fulton JE, et al. Genomewide association study for egg production and quality in layer chickens. J Anim Breed Genet. 2014;131(3):173-82. https://doi.org/10.1111/jbg.12086.

13. Liu W, Li D, Liu J, Chen S, Qu L, Zheng J, et al. A genome-wide SNP scan reveals novel loci for egg production and quality traits in white leghorn and brown-egg dwarf layers. Plos One. 2011;6(12):e28600. https://doi.org/10.13 71/journal.pone.0028600.

14. Yuan J, Sun C, Dou T, Yi G, Qu L, Qu L, et al. Identification of promising mutants associated with egg production traits revealed by genome-wide association study. Plos One. 2015;10(10):e0140615. https://doi.org/10.1371/ journal.pone.0140615.

15. Zhang GX, Fan QC, Wang JY, Zhang T, Xue Q, Shi HQ. Genome-wide association study on reproductive traits in Jinghai yellow chicken. Anim Reprod Sci. 2015;163:30-4. https://doi.org/10.1016/j.anireprosci.2015.09.011.

16. Liao R, Zhang X, Chen Q, Wang Z, Wang Q, Yang C, et al. Genome-wide association study reveals novel variants for growth and egg traits in Dongxiang blue-shelled and white Leghorn chickens. Anim Genet. 2016; 47(5):588-96. https://doi.org/10.1111/age.12456.

17. Hu ZL, Park CA, Wu XL, Reecy JM. Animal QTLdb: an improved database tool for livestock animal QTL/association data dissemination in the post- genome era. Nucleic Acids Res. 2013;41(Database issue):D871-9. https://doi. org/10.1093/nar/gks1150.

18. Price AL, Zaitlen NA, Reich D, Patterson N. New approaches to population stratification in genome-wide association studies. Nat Rev Genet. 2010;11(7): 459-63. https://doi.org/10.1038/nrg2813.

19. Jiang $Y$, Tang $S$, Wang C, Wang $Y$, Qin Y, Wang Y, et al. A genome-wide association study of growth and fatness traits in two pig populations with different genetic backgrounds. J Anim Sci. 2018;96(3):806-16. https://doi. org/10.1093/jas/skx038.

20. Ryu BJ, Kim HR, Jeong JK, Lee BJ. Regulation of the female rat estrous cycle by a neural cell-specific epidermal growth factor-like repeat domain containing protein, NELL2. Mol Cells. 2011;32(2):203-7. https://doi.org/10.1 007/s10059-011-0086-7.

21. An XP, Hou JX, Li G, Song YX, Wang JG, Chen QJ, et al. Polymorphism identification in the goat KTLG gene and association analysis with litter size. Anim Genet. 2012; 43(1):104-7. https://doi.org/10.1111/j.1365-2052.2011.02219x.

22. An XP, Hou JX, Lei YN, Gao TY, Song YX, Wang JG, et al. Two mutations in the 5 -flanking region of the KITLG gene are associated with litter size of dairy goats. Anim Genet. 2015;46(3):308-11. https://doi.org/10.1111/age.12277.

23. An XP, Hou JX, Gao TY, Lei YN, Song YX, Wang JG, et al. Association analysis between variants in KITLG gene and litter size in goats. Gene. 2015;558(1): 126-30. https://doi.org/10.1016/j.gene.2014.12.058.

24. Liu W, Yu Y, Li G, Tang S, Zhang Y, Wang Y, et al. Single-nucleotide polymorphisms in the promoter of the growth hormone-releasing hormone receptor gene are associated with growth and reproduction traits in chickens. Anim Genet. 2012;43(5):564-9. https://doi.org/10.1111/j.1365-2 052.2011.02306.x.

25. Kamei Y, Xu L, Heinzel T, Torchia J, Kurokawa R, Gloss B, et al. A CBP integrator complex mediates transcriptional activation and AP-1 inhibition by nuclear receptors. Cell. 1996;85(3):403-14. https://doi.org/10.1016/500928674(00)81118-6.

26. Razeto A, Ramakrishnan V, Litterst CM, Giller K, Griesinger C, Carlomagno T, et al. Structure of the NCOA-1/SRC-1 PAS-B domain bound to the LXXLL motif of the STAT6 transactivation domain. J Mol Biol. 2004;336(2):319-29. https://doi.org/10.1016/j.jmb.2003.12.057.

27. Glass CK. Differential recognition of target genes by nuclear receptor monomers, dimers, and heterodimers. Endocr Rev. 1994;15(3):391-407. https://doi.org/10.1210/edrv-15-3-391.

28. Yuan Z, Zhang J, Li W, Wang W, Li F, Yue X. Association of Polymorphisms in Candidate Genes with the Litter Size in Two Sheep Breeds. Animals (Basel). 2019;9(11):958

29. Gholami M, Erbe M, Gärke C, Preisinger R, Weigend A, Weigend S, et al. Population genomic analyses based on 1 million SNPs in commercial egg layers. Plos One. 2014;9(4):e94509. https:/doi.org/10.1371/journal.pone.0094509.

30. Huang HY, Li SF, Zhao ZH, Liang Z, Zhang J, Ding YR. Association of polymorphisms for nuclear receptor coactivator 1 gene with egg production traits in the maternal line of Shaobo hens. Br Poult Sci. 2011; 52(3):328-32. https://doi.org/10.1080/00071668.2011.577057.

31. Tarsani E, Kranis A, Maniatis G, Avendano S, Hager-Theodorides AL, Kominakis A. Deciphering the mode of action and position of genetic variants impacting on egg number in broiler breeders. BMC Genomics. 2020;21 (1):512. https://doi.org/10.1186/s12864-020-06915-1.

32. Singh V, Bala R, Chakraborty A, Rajender S, Trivedi S, Singh K. Duplications in 19p13.3 are associated with male infertility. J Assist Reprod Genet. 2019; 36(10):2171-9. https://doi.org/10.1007/s10815-019-01547-1.

33. Zhang H, Yu JQ, Yang LL, Kramer LM, Zhang XY, Na W, et al. Identification of genome-wide SNP-SNP interactions associated with important traits in chicken. BMC Genomics. 2017;18(1):892. https://doi.org/10.1186/s12864-01 7-4252-y.

34. Griffith GJ, Trask MC, Hiller J, Walentuk M, Pawlak JB, Tremblay KD, et al. Yinyang 1 is required in the mammalian oocyte for follicle expansion. Biol Reprod. 2011;84(4):654-63. https://doi.org/10.1095/biolreprod.110.087213.

35. Jin F, Dai J, Ji C, Gu S, Wu M, Qian J, et al. A novel human gene (WDR25) encoding a 7-WD40-containing protein maps on 14q32. Biochem Genet. 2004;42(11-12):419-27. https://doi.org/10.1023/B:BIGI.0000043954.64202.61.

36. Deguchi M, Hata Y, Takeuchi M, Ide N, Hirao K, Yao I, et al. BEGAIN (brainenriched guanylate kinase-associated protein), a novel neuronal PSD-95/ SAP90-binding protein. J Biol Chem. 1998;273(41):26269-72. https://doi. org/10.1074/jbc.273.41.26269.

37. Raeesi V, Ehsani A, Torshizi RV, Sargolzaei M, Masoudi AA, Dideban R. Genome-wide association study of cell-mediated immune response in 
chicken. J Anim Breed Genet. 2017;134(5):405-11. https://doi.org/10.1111/ jbg. 12265.

38. Willson NL, Forder REA, Tearle RG, Nattrass GS, Hughes RJ, Hynd PI. Evaluation of fatty acid metabolism and innate immunity interactions between commercial broiler, F1 layer $\times$ broiler cross and commercial layer strains selected for different growth potentials. J Anim Sci Biotechnol. 2017; 8(1):70. https://doi.org/10.1186/s40104-017-0202-4.

39. Griffin HD, Butterwith SC, Goddard C. Contribution of lipoprotein lipase to differences in fatness between broiler and layer-strain chickens. Br Poult Sci. 1987;28(2):197-206. https://doi.org/10.1080/00071668708416953.

40. Sato M, Tachibana T, Furuse M. Heat production and lipid metabolism in broiler and layer chickens during embryonic development. Comp Biochem Physiol A Mol Integr Physiol. 2006;143(3):382-8. https://doi.org/10.1016/j. cbpa.2005.12.019.

41. Maggi R, Cariboni AM, Marelli MM, Moretti RM, Andrè V, Marzagalli M, et al. $\mathrm{GnRH}$ and GnRH receptors in the pathophysiology of the human female reproductive system. Hum Reprod Update. 2016;22(3):358-81. https://doi. org/10.1093/humupd/dmv059.

42. Ma Y, Ladisa C, Chang. JP. Habibi HR. Multifactorial control of reproductive and growth axis in male goldfish: influences of $\mathrm{GnRH}, \mathrm{GnIH}$ and thyroid hormone. Mol Cell Endocrinol. 2020;500:110629. https://doi.org/10.1016/j. mce.2019.110629.

43. Prapaiwan N, Manee-In S, Olanratmanee E, Srisuwatanasagul S. Expression of oxytocin, progesterone, and estrogen receptors in the reproductive tract of bitches with pyometra. Theriogenology. 2017;89:131-9. https://doi.org/10.1 016/j.theriogenology.2016.10.016.

44. Ji H, Liu N, Yin Y, Wang $X$, Chen $X$, Li J, et al. Oxytocin inhibits ovarian cancer metastasis by repressing the expression of MMP-2 and VEGF. J Cancer. 2018;9(8):1379-84. https://doi.org/10.7150/jca.23769.

45. Hull KL, Harvey S. Growth hormone and reproduction: a review of endocrine and autocrine/paracrine interactions. Int J Endocrinol. 2014;2014: 234014

46. Cai YY, Lin N, Zhong LP, Duan HJ, Dong YH, Wu Z, et al. Serum and follicular fluid thyroid hormone levels and assisted reproductive technology outcomes. Reprod Biol Endocrinol. 2019;17(1):90. https://doi.org/10.1186/s12 958-019-0529-0.

47. Zhou SS, Li P. Effects of NELL2 on the regulation of GnRH expression and puberty in female rats. Genet Mol Res. 2014;13(3):6672-82. https://doi.org/1 0.4238/2014.August.28.12.

48. Sun YX, Zhang YX, Zhang D, Xu CM, Chen SC, Zhang JY, et al. XCl-escaping gene KDM5C contributes to ovarian development via downregulating miR320a. Hum Genet. 2017;136(2):227-39. https://doi.org/10.1007/s00439-016-1 752-9.

49. Dettori ML, Pazzola M, Paschino P, Amills M, Vacca GM. Association between the GHR, GHRHR, and IGF1 gene polymorphisms and milk yield and quality traits in Sarda sheep. J Dairy Sci. 2018;101(11):9978-86. https://doi.org/10.31 68/jds.2018-14914.

50. Wu JY, Gonzalez-Robayna IJ, Richards JS, Means AR. Female fertility is reduced in mice lacking $\mathrm{Ca} 2+$ /calmodulin-dependent protein kinase IV. Endocrinology. 2000;141(12):4777-83. https://doi.org/10.1210/endo.141.12. 7826.

51. Nie C, Zhang Z, Zheng J, Sun H, Ning Z, Xu G, et al. Genome-wide association study revealed genomic regions related to white/red earlobe color trait in the Rhode Island red chickens. BMC Genet. 2016;17(1):115. https://doi.org/10.1186/s12863-016-0422-1.

52. Kranis A, Gheyas AA, Boschiero C, Turner F, Yu L, Smith S, et al. Development of a high density 600K SNP genotyping array for chicken. BMC Genomics. 2013;14(1):59. https://doi.org/10.1186/1471-2164-14-59.

53. Purcell S, Neale B, Todd-Brown K, Thomas L, Ferreira MA, Bender D, et al. PLINK: a tool set for whole-genome association and population-based linkage analyses. Am J Hum Genet. 2007;81(3):559-75. https://doi.org/10.1 086/519795

54. Alexander DH, Novembre J, Lange K. Fast model-based estimation of ancestry in unrelated individuals. Genome Res. 2009;19(9):1655-64. https://doi.org/10.1101/gr.094052.109.

55. Francis RM. Pophelper: an R package and web app to analyse and visualize population structure. Mol Ecol Resour. 2017;17(1):27-32. https://doi.org/1 $0.1111 / 1755-0998.12509$

56. Zhou X, Stephens M. Genome-wide efficient mixed-model analysis for association studies. Nat Genet. 2012;44(7):821-4. https://doi.org/10.1038/ ng.2310.
57. Shen M, Qu L, Ma M, Dou T, Lu J, Guo J, et al. Genome-wide association studies for comb traits in chickens. PLoS One. 2016;11(7):e0159081. https://doi.org/10.1371/journal.pone.0159081.

58. Bland JM, Altman DG. Multiple significance tests: the Bonferroni method. BMJ. 1995;310(6973):170. https://doi.org/10.1136/bmj.310.6973.170.

59. Nicodemus KK, Liu W, Chase GA, Tsai Y-Y, Fallin MD. Comparison of type I error for multiple test corrections in large single-nucleotide polymorphism studies using principal components versus haplotype blocking algorithms BMC Genet. 2005;6(1):S78. https://doi.org/10.1186/1471-2156-6-S1-S78.

\section{Publisher's Note}

Springer Nature remains neutral with regard to jurisdictional claims in published maps and institutional affiliations.
Ready to submit your research? Choose BMC and benefit from:

- fast, convenient online submission

- thorough peer review by experienced researchers in your field

- rapid publication on acceptance

- support for research data, including large and complex data types

- gold Open Access which fosters wider collaboration and increased citations

- maximum visibility for your research: over $100 \mathrm{M}$ website views per year

At BMC, research is always in progress.

Learn more biomedcentral.com/submissions 